\title{
DANA TALANGAN HAJI: ANTARA KEBUTUHAN DAN IRONI
}

\author{
Oleh: \\ Citra Ayudiati* \\ Universitas Cokroaminto Yogyakarta
}

\begin{abstract}
Abstrak
Untuk lembaga keuangan syariah agar menerapkan fatwa DSN dan tidak keluar dari fatwa, yaitu menarik biaya admnistrasi yang nyata-nyata diperlukan dengan besaran biaya tetap, tidak berdasarkan besarnya pinjaman. Jika ini dilanggar, maka akan menyebabkan terjaruh ke dalam praktik riba. Untuk DSN, selain mengeluarkan fatwa diharapkan dapat memberikan sanksi bagi lembaga-lembaga yang menerapkan produk tidak sesuai dengan yang difatwakan melalui Dewan Pengawas Syariah yang terdapat di setiap bank syariah.

Untuk masyarakat yang mendaftar haji jangan sampai terjebak dalam produk ini karena mengandung syubhat riba yang berakibat terhadap kemabruran hajinya karena berangkat menggunakan harta yang diperoleh dengan cara riba. Hendaklah ia membayar tunai sebanyak Rp 20 juta agar bisa mendapatkan kepastian seat (nomor urut) untuk tahun keberangkatan, dan jangan menggunakan dana talangan bank.
\end{abstract}

Kata Kunci: Dana Talangan Haji, Kebutuhan dan Ironi

\section{Pendahuluan}

Pengertian dana talangan haji adalah pinjaman dari Lembaga Keuangan Syariah kepada nasabah untuk menutupi kekurangan dana guna memperoleh kursi haji pada saat pelunasan BPIH (Biaya Perjalanan Haji Indonesia) Bagi nasabah yang memiliki kekurangan dana untuk berangkat maka disinilah peran lembaga keuangan syariah untuk memberikan talangan atau pinjaman dimana nanti LKS juga akan menguruskan berkas berkas sampai nasabah tersebut mendapatkan nomor antrian. Dan atas jasa tersebut maka LKS mendapatkan ujroh (uang jasa) atas pengurusan haji tersebut. Landasan diperbolehkannya penggunaan dana talangan untuk berhaji :

Al Baqarah ayat 282 , Kesaksian dalam mu'amalah

"Hai orang-orang yang beriman, apabila kamu bermu'amalah ${ }^{[179]}$ tidak secara tunai untuk waktu yang ditentukan, hendaklah kamu menuliskannya. Dan hendaklah seorang penulis di antara kamu menuliskannya dengan benar. Dan janganlah penulis enggan menuliskannya sebagaimana Allah mengajarkannya, meka hendaklah ia menulis, dan hendaklah orang yang 
berhutang itu mengimlakkan (apa yang akan ditulis itu), dan hendaklah ia bertakwa kepada Allah Tuhannya, dan janganlah ia mengurangi sedikitpun daripada hutangnya. Jika yang berhutang itu orang yang lemah akalnya atau lemah (keadaannya) atau dia sendiri tidak mampu mengimlakkan, maka hendaklah walinya mengimlakkan dengan jujur. Dan persaksikanlah dengan dua orang saksi dari orang-orang lelaki (di antaramu). Jika tak ada dua oang lelaki, maka (boleh) seorang lelaki dan dua orang perempuan dari saksi-saksi yang kamu ridhai, supaya jika seorang lupa maka yang seorang mengingatkannya. Janganlah saksi-saksi itu enggan (memberi keterangan) apabila mereka dipanggil; dan janganlah kamu jemu menulis hutang itu, baik kecil maupun besar sampai batas waktu membayarnya. Yang demikian itu, lebih adil di sisi Allah dan lebih menguatkan persaksian dan lebih dekat kepada tidak (menimbulkan) keraguanmu. (Tulislah mu'amalahmu itu), kecuali jika mu'amalah itu perdagangan tunai yang kamu jalankan di antara kamu, maka tidak ada dosa bagi kamu, (jika) kamu tidak menulisnya. Dan persaksikanlah apabila kamu berjual beli; dan janganlah penulis dan saksi saling sulit menyulitkan. Jika kamu lakukan (yang demikian), maka sesungguhnya hal itu adalah suatu kefasikan pada dirimu. Dan bertakwalah kepada Allah; Allah mengajarmu; dan Allah Maha Mengetahui segala sesuatu. “

[179]. Bermuamalah ialah seperti berjualbeli, hutang piutang, atau sewa menyewa dan sebagainya.

Al Qashash ayat 26

“Salah seorang dari kedua wanita itu berkata: "Ya bapakku ambillah ia sebagai orang yang bekerja (pada kita), karena sesungguhnya orang yang paling baik yang kamu ambil untuk bekerja (pada kita) ialah orang yang kuat lagi dapat dipercaya."

Ketentuan umum dalam fatwa DSN MUI tentang Dana Talangan Haji :

1. Dalam pengurusan haji bagi nasabah, LKS dapat memperoleh imbalan jasa (ujrah) dengan menggunakan prnsip al ijarah sesuai dengan fatwa DSN MUI nomor 9/DSN MUI/IV/2000

2. Apabila diperlukan LKS dapat membantu menalangi pembayaran BPIH nasabah dengan menggunakan prinsip al Qardh sesuai dengan fatwa DSN MUI nomor 19/DSN MUI/IV/2000

3. Jasa pengurusan haji yang dilakukan LKS tidak boleh dipersyaratkan dengan pemberian talangan haji, 
4. Besar imbalan jasa al ijarah tidak boleh didarkan pada jumlah talangan al Qardh yang diberikan LKS kepada nasabah

\section{Penjelasan Fatwa DSN MUI}

Penjelasan mengenai fatwa DSN MUI tentang penggunaan 2 akad tersebut telah sesuai namun apakah itu semua telah dilaksanakan dengan jelas oleh Bank Syariah. Hal ini yang masih menjadi polemik, dalam ketentuan fatwa MUI pada bagian pengurusan haji disana telah diebutkan bahwa LKS tidak boleh dipersyaratkan dengan pemberian talangan haji. Namun pada prakteknya dilapangan kita telah menjumpai bahwa Bank Syariah yang memberikan talangan pasti juga akan mempersyaratkan pengurusan hajinya dengan mereka. Dan jelas hal ini telah melanggar fatwa MUI pada ketentuan yang ke 3. Dasar dari larangan ini dapat kita lihat sebagai berikut :

1. Hadist Abdullah bin Amru radhiyalluanhu

"Dari Abdullah bin Amru ia berkata ," Rasulullah SAW bersabda : "Tidak halal menjual sesuatu dengan syarat memberikan hutangan, dua syarat dalam satu transaksi, keuntungan menjual sesuatu yang belum engkai jamin, serta menjual sesuatu yang bukan milikmu." (HR. Abu Dawud dan Tirmidzi sanadnya Shahih)

2. Kaidah fiqh yang disarikan dari hadist

"Setiap pinjaman yang membawa manfaat (bagi pemberi pinjaman) adalah riba

3. Pinjaman adalah kegiatan social yang bertujuan membentu sesame dan mencari pahala dari Allah sehingga Allah tidak boleh dimanfaatkan untuk mengambil keuntungan.

\section{Tinjauan fiqih berhaji dengan Hutang Tinjauan Fiqih}

Jika diperhatikan secara seksama, maka didapati bahwa dalam produk dana talangan haji ini ada dua akad yang digabung dalam sebuah produk. Kedua akad tersebut Adalah akad qardh (pinjam meminjam) dalam bentuk pemberian talangan dana haji dari pihak bank kepada pendaftar haji. Akad yang kedua Adalah ijarah (jual beli jasa) dalam bentuk ujrah (fee administrasi yang diberikan oleh pendaftar haji sebagai pihak terhutang kepada LKS atau bank sebagai pemberi pinjaman). 
Menggabungkan akad qardh dengan ijarah telah dilarang oleh Rasulullah صلى الله عليه وسلم:

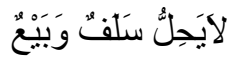

Tidak halal menggabungkan akad pinjaman dan akad jual beli. (HR. Abu Daud dan dishahihkan oleh al-Albani رحمه الله) Dan akad ijarah termasuk akad jual-beli yaitu jual-beli jasa.

Dengan demikian, produk dana talangan haji ini bertentanggan dengan hadits Nabi di atas karena dalam produk tersebut digabungkan dua akad tersebut. Alasan lainnya, akad ijarah ini bisa dimanfaatkan oleh pemberi pinjaman untuk mengambil laba dari pinjaman yang diberikan sehingga termasuk dalam larangan pinjaman yang mendatangkan manfaat (keuntungan).

Namun bila pintu pengambilan keuntungan ini dapat ditutup rapat maka bisa saja digunakan sebagaimana difatwakan oleh berbagai lembaga fikih Nasional dan Internasional. Sebagaimana yang dinyatakan dalam fatwa DSN yang membolehkan mengambil biaya administrasi yang nyata-nyata diperlukan dalam jumlah tetap dan bukan berdasarkan besarnya pinjaman. Namun ternyata fatwa tersebut tidak dijalankan pada praktek yang dijelaskan sebelumnya, dimana (besarnya biaya administrasi bervariasi berdasarkan besarnya pinjaman yang diberikan oleh pihak bank. Ini jelas-jelas bahwa pihak bank tidak sekedar menarik biaya admninistrasi yang nyata-nyata diperlukan akan tetapi di sana telah dimasukkan laba dari pinjaman. Maka jelas ini hukumnya termasuk riba.

Jika dilihat dari persentase besarnya biaya administrasi ini, yaitu sekitar $10 \%$ dari besarnya pinjaman, ini hampir sama dengan bunga pinjaman yang ditarik oleh bank konyensional. Berangkat haji adalah impian setiap muslim yang ada didunia, dengan peluh dan keringat sebagian dari umat muslim khususnya yang ada di Indonesia dikerjakan untuk mengumpulkan ongkos guna berangkat haji dan kenyataannya mereka mampu mberangkat namun dengan usia yang telah menjelang senja. Begitu besar kerinduan umat Islam ini untuk berangkat haji menjadi muncul sebuah fenomena yang dinamakan dana talangan haji. Fenomena ini begitu cepat menjadi idola bagi umat muslim yang merasa tabungan hajinya jauh dari cukup dan begitu sangat ingin berangkat haji namun sangat disayangkan ternyata praktek yang selam ini ada didalam masyarakat masih belumbisa sempurna. Kurangnya kehati hatian kita dalam 
mengkaji ilmu bisa menjadi salah satu alasan mengapa praktek ini menurut kami masih meragukan kehalalannya. Walaupun Dewan Syariah Nasional telah mengeluarkan fatwa namun hendaknya kita juga mengkaji segala sesuatu dengan sifat uyang kritis dan berhati hati apalagi ini terkait dengan perjalanan ibadah haji. Nah kami akan coba untuk membedah dengan lebih hati hati apa sebenarnya yang dimaksud dengan dana talangan haji yang dijasikan salah satu cara untuk mendaftar haji. Kalo kita bisa mencermati mengenai akad yang ada didalam talangan haji maka kita akan menemukana 2 akad yang berbeda yang digabungkan menjadi satu. Yaitu akad Qardh (piutang) dan akad Ijarah (sewa menyewa). Dan masing masing akad ini adaah halal jika kita melakukannya secara ter pisah. Namun apabila kedua akad ini dijadikan satu bagaimanakah seharusnya, maka disini kita akan coba melihat berdasarkan dalil dan juga tuntunan yang Allah SWT berikan kepada Rasulullah Muhammad SAW.

Beberapa hadist yang mengacu pada hal ini

1. "Tidak halal menggabungkan antara piutang dengan akad jual beli ". (HR. Abu Dawud) Syaikhul Islam Ibnu Taimiyah berkata, “ pada hadist ini Nabi Muhammad SAW melarang penggabungan antara piutang dengan akad jual beli. Dengan demikian jika kita menggabungkan antara akad utang piutang dan sewa menyew, dengan demikian setiap akad social semisal hibah pinjam meminjam, hibah buah buahan yang masih diatas pohonnnya, diskon pada akan penggarapan lading atau sawah dan lainya semakna dengan akad utang piutang yaitu tidak boleh digabungkan dengan akad jual beli dan sewa menyewa," (majmu fatawa Ibnu Taimiyah 29/62)

2. Riba terselubung. Secara lahir kreditur tidak emungut tambahan atau riba atau bunga dari piutangnya, namun secara tidak langsung ia telah emndapatkannya yaitu dari uang sewa yang ia pungut. Seaw menyewa jual jas pengurusan haji ) yang dilakukan oeh lembaga keuangan terkait langsung dengan akad utang piutang. Biasanya yang telah memiliki dana sendiri untuk biaya hajinya tidak akan menggunakan layanan dana talangan ini. Dengan demikian adanya talangan haji ini menjadikan lembaga keuangan terkait dapat memasarkan jasanya dan pasti mendapatkan keuntungan dari jual beli jasa tersebut. Syakhul Islam Ibnu Taimiyah menjelaskan hal ini dengan berkata, "Kesimpulan dari hadist ini meeaskan bahwa, “ Tidak dibenarkan menggabungkan antara akad komersial dengan akad social. Yang 
demikian itu karena keduanya menjalin akad social disebabkan adanya akad komersial antara mereka. Dengan demikian akad ini tidak sepenuhnya akad social.

3. Memberatkan masyarakat. Adanya praktek memaksakan diri ini tidak diragukan membebani masyarakat. Terlebih lebih menjadikan agama islam yang awalnya teras mudah menjadi berat dan sulit. Untuk dapat berhaji harus menunggu sekian lama dan mereka juga harus membayar cicilan piutang. Hal nini sangatlah bertentangan syariat Islam. "Wahai umat manusia, hendaknya kalian mengerjakan amalan yang kuasa kalian kerjakan, karena sejatinya Allah tidak pernah merasa bosan (diibadahi) walaupun kalian sudah merasakannya. Dan sesungguhnya amalan yang paling dicintai Allah Adalah amalan yang dilakukan secara terus menerus." (HR. Bukhari).

Dalam urusan haji Allah Ta'ala berfirman :

“Mengerjakan haji adalah kewajiban manusia terhadap Allah, yaitu (bagi) orang yang sanggup mengadakan perjalan ke Baitullah ." (QS. Ali Imron : 97)

\section{Bentuk dan Akad Talangan Haji}

Seseorang yang ingin mendaftar haji mendatangi salah satu lembaga keuangan syariah lalu mendaftarkan diri untuk haji dengan membuka rekening tabungan haji, serta membayar saldo minimal Rp 500 ribu. Kemudian agar ia mendapatkan kepastian seat (kursi) untuk tahun berapa maka ia harus melunasi sebanyak Rp 20 juta . Bank dapat memberikan dana talangan dengan pilihan Rp 10 juta, Rp 15 juta, Rp 18 juta.

Andai pendaftar memilih talangan Rp 18 juta berarti ia mengeluarkan dana tunai pribadinya sebesar Rp 2 juta. Dan 18 juta akan ditalangi oleh Lembaga keuangan Syariah. Utang pendaftar ini ke Lembaga Keuangan Syari'at (Selanjutnya akan disingkat menjadi LKS) sebanyak Rp 18 juta akan dibayar secara angsuran selama satu tahun ditambah dengan biaya administrasi sebanyak Rp 1,5 juta. Sehingga yang harus dibayar ke LKS sebanyak Rp 19,5 juta. Jika dalam setahun tidak terlunasi hutangnya kepada bank maka ia dikenakan biaya administrasi baru. Andai pendaftar memilih talangan sebesar Rp 15 juta berarti ia mengeluarkan dana pribadinya sebesar Rp 5 juta tunai, sementara Rp 15.000.000,-akan ditalangi oleh LKS. Utang pendaftar yang berjumlah Rp. 15.000.000,- akan dibayarkan ke LKS secara angsuran selama 1 tahun ditambah dengan biaya administrasi sebanyak Rp 1,3 juta. Sehingga yang harus 
dibayarnya ke LKS sebanyak Rp 16, 3 juta. Jika dalam setahun tidak terlunasi hutangnya kepada LKS maka ia dikenakan biaya administrasi baru. Andai pendaftar memilih talangan Rp 10 juta berarti ia mengeluarkan dana pribadinya sebesar Rp 10 juta tunai. Dan 10 juta akan ditalangi oleh Lembaga keuangan Syariah. Utang pendaftar ini ke LKS sebanyak Rp 10 juta akan dibayar secara angsuran selama 1 tahun ditambah dengan biaya administrasi sebanyak Rp 1 juta. Sehingga yang harus dibayarnya ke LKS sebanyak Rp 11 juta. Jika dalam setahun tidak terlunasi hutangnya kepada bank maka ia dikenakan biaya administrasi baru.

\section{Himbauan}

Untuk lembaga keuangan syariah agar menerapkan fatwa DSN dan tidak keluar dari fatwa, yaitu menarik biaya admnistrasi yang nyata-nyata diperlukan dengan besaran biaya tetap, tidak berdasarkan besarnya pinjaman. Jika ini dilanggar, maka akan menyebabkan terjaruh ke dalam praktik riba. Untuk DSN, selain mengeluarkan fatwa diharapkan dapat memberikan sanksi bagi lembaga-lembaga yang menerapkan produk tidak sesuai dengan yang difatwakan melalui Dewan Pengawas Syariah yang terdapat di setiap bank syariah. Untuk masyarakat yang mendaftar haji jangan sampai terjebak dalam produk ini karena mengandung syubhat riba yang berakibat terhadap kemabruran hajinya karena berangkat menggunakan harta yang diperoleh dengan cara riba. Hendaklah ia membayar tunai sebanyak Rp 20 juta agar bisa mendapatkan kepastian seat (nomor urut) untuk tahun keberangkatan, dan jangan menggunakan dana talangan bank. Bagi yang telah terlanjur, maka ingatlah firman Allah رحمه الله:

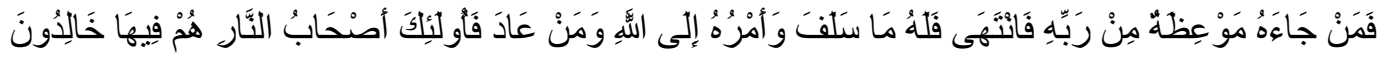

Orang-orang yang telah sampai kepadanya larangan dari Rabbnya, lalu terus berhenti (dari mengambil riba), maka baginya apa yang telah diambilnya dahulu (sebelum datang larangan); dan urusannya (terserah) kepada Allah. Orang yang kembali (mengambil riba), maka orang itu Adalah penghuni-penghuni neraka; mereka kekal di dalamnya. (QS. alBaqarah/2:275).

Dan hendaklah ia berusaha sekuat tenaga untuk menutupi sisa talangan secepatnya. Semoga Allah menerima ibadah haji umat Islam. 


\section{Daftar Pustaka}

Antonio, Syafi,i. M. 2001. Bank Syariah Dari Teori ke Praktek. Jakarta: Gema Insan Press.

Ash-Shawi, Shalah dan al-Muslih, Abdullah, 2001. Fikih ekonomi Keuangan Islam. Jakarta: Darul Haq.

Fatwa DSn tantang Dana talangan Haji.

Muhammad. 2002. Lembaga KeuanganUmat Kontemporer. Yogyakarta: UII Press.

Muhammad, Rifqi.2008. Akuntansi Keuangan Syariah. Yogyakarta: UUI Press.

Solihin, Ahmad Ifham.2010. Buku Pintar Ekonomi Syariah. Jakarta: Gramedia.

Warde, Ibrahim. 2009. Islamic Finance: Keuangan Islam Dalam Perekonomian Global. Yogyakarta : Pustaka Pelajar.

Zulkifli, Sunato. 2003. Panduan Praktis Transaksi Perbankan Syariah. Jakarta: Zikrul Hakim. 